\title{
Pertumbuhan Tanaman Nilam MV1 Varietas Lhokseumawe Akibat Konsentrasi dan Lama Perendaman Kolkisin
}

\section{The Growth of MV1 Patchouli Plants in Lhokseumawe Variety Due to Concentration and Immersion Time of Colchicine}

\author{
Zuyasna", Ainun Marliah, Adinda Rahayu, Erita Hayati, Rika Husna \\ Jurusan Agroteknologi Fakultas Pertanian, Universitas Syiah Kuala, Banda Aceh \\ `Email korespondensi: zuyasna@unsyiah.ac.id
}

\begin{abstract}
This study aims to determine the best colchicine concentration and immersion time in the colchicine induction process to obtain the highest level of diversity. The research was conducted at Sektor Timur Experimental Garden 2, Faculty of Agriculture, Syiah Kuala University, Darussalam, Banda Aceh, which was conducted from June to August 2020. This research used a factorial Randomized Complete Block Design $(R C B D)$ with two factors. The first factor is the concentration of colchicine solution with 4 levels $(0 \%, 1 \%$, $2 \%, 3 \%)$ and the second factor is the immersion time with 4 levels $(2,4,6$, and 8 hours). There were 16 treatment combinations with each treatment repeated 4 times, and therefore 64 experimental units obtained. Parameters observed included increase in plant height, increase in diameter, number of branches, number of shoots, number of leaves, length of branches and leaf surface area. The results showed that the colchicine concentration had a significant effect on the surface area of the leaves after treatment (90 HSP), with the highest average occurring at the 3\% colchicine concentration treatment. The duration of immersion with colchicine did not significantly affect all the variables observed. The combination of colchicine concentration treatment with immersion time had a significant effect on the number of patchouli plant branches at the age of $30 \mathrm{HSP}$, where the highest number of branches was at $2 \%$ colchicine concentration with 6 hours of soaking time.
\end{abstract}

Keywords: colchicine concentration, diversity, immersion time, induction

\begin{abstract}
Abstrak. Penelitian ini bertujuan untuk mengetahui konsentrasi kolkisin dan waktu perendaman terbaik dalam proses induksi kolkisin untuk mendapatkan tingkat keragaman tertinggi. Penelitian dilaksanakan di Kebun Percobaan 2 Sektor Timur, Fakultas Pertanian, Universitas Syiah Kuala, Darussalam, Banda Aceh yang dilaksanakan dari bulan Juni sampai Agustus 2020. Penelitian ini dilaksanakan dengan menggunakan Rancangan Acak Kelompok (RAK) faktorial dengan dua faktor. Faktor pertama yaitu konsentrasi larutan kolkisin dengan 4 taraf $(0 \%, 1 \%, 2 \%, 3 \%)$ dan faktor kedua yaitu lama perendaman dengan 4 taraf (2 jam, 4 jam, 6 jam, 8 jam). Terdapat 16 kombinasi perlakuan dengan masing-masing perlakuan diulang 4 kali, sehingga diperoleh 64 satuan percobaan. Parameter yang diamati meliputi pertambahan tinggi tanaman, pertambahan diameter, jumlah cabang, jumlah tunas, jumlah daun, panjang cabang dan luas permukaan daun. Hasil penelitian menunjukkan bahwa konsentrasi kolkisin berpengaruh nyata terhadap luas permukaan daun setelah perlakuan (90 HSP), dengan rataan tertinggi terjadi pada perlakuan konsentrasi kolkisin $3 \%$. Lama perendaman dengan kolkisin tidak berpengaruh nyata pada semua peubah yang diamati. Kombinasi perlakuan konsentrasi kolkisin dengan lama perendaman berpengaruh nyata terhadap jumlah cabang tanaman nilam pada umur 30 HSP, dimana jumlah cabang terbanyak terdapat pada konsentrasi kolkisin $2 \%$ dengan lama perendaman 6 jam. Kata kunci: induksi, konsentrasi kolkisin, keragaman, lama perendaman
\end{abstract}

\section{PENDAHULUAN}

Tanaman nilam (Pogostemon cablin Benth.) merupakan tanaman perkebunan penghasil minyak atsiri yang mempunyai nilai ekonomi tinggi di dunia. Tanaman ini termasuk salah satu penyumbang devisa yang tinggi bagi negara (Hariyani et al., 2015). Minyak atsiri dari tanaman nilam dihasilkan melalui proses penyulingan daun serta cabang tanaman yang sudah dipanen.
Kurniasari (2010) menjelaskan bahwa minyak nilam atau yang dikenal dengan Patchouli oil digunakan sebagai bahan pencampur dalam industri parfum dan kosmetik karena memiliki sifat fiksatif yang sampai saat ini belum bisa digantikan perannya. Perkembangan industri saat ini menyebabkan kebutuhan minyak nilam semakin meningkat dan sebagai komoditi ekspor, minyak nilam dibutuhkan secara 
berkelanjutan.

Indonesia umumnya memiliki tiga jenis nilam yang sudah dibudidayakan oleh para petani yaitu nilam Aceh (Pogostemon cablin), nilam Jawa (Pogostemon heyneanus) dan nilam sabun (Pogostemon hortensis). Jenis nilam yang paling banyak dibudidayakan ialah nilam Aceh karena memiliki kualitas minyak yang lebih tinggi daripada lainnya (Anne, 2012). Nilam Aceh juga dibedakan menjadi tiga varietas berdasarkan daerah penghasil utama yaitu varietas Lhokseumawe, varietas Tapaktuan dan varietas Sidikalang. Ketiga varietas nilam ini memiliki kelebihan dan karakteristik yang berbeda satu sama lain.

Indonesia dikenal memiliki mutu minyak nilam yang paling baik di dunia sehingga menjadi pemasok minyak nilam terbesar di dunia dengan kontribusi mencapai $90 \%$ dari kebutuhan dunia. Walaupun demikian, produksi nilam setiap tahunnya tidak stabil dan cenderung menurun. Produksi nilam di Provinsi Aceh tahun 2015 adalah 645 ton, pada tahun 2016 mengalami penurunan produksi menjadi 466 ton, lalu pada tahun 2017 hampir sama dengan tahun sebelumnya yaitu 468 ton, selanjutnya di tahun 2018 mengalami penurunan drastis yaitu menjadi 178 ton dan pada tahun 2019 kembali mengalami kenaikan produksi menjadi 354 ton (Ditjenbun, 2020).

Produksi nilam di Indonesia sampai saat ini belum optimal dan masih banyak permasalahan yang dialami petani dalam budidaya tanaman nilam yang berakibat pada kualitas nilam yang dihasilkan. Hal ini besar kaitannya dengan sumber genetik tanaman nilam di Indonesia yang masih terbatas sehingga perbaikan tanaman dengan teknik hibridisasi sulit dilakukan. Tanaman nilam sulit menghasilkan bunga sehingga sulit untuk mendapatkan keragaman genetik baru dengan sifat yang diharapkan (Afifah, 2015). Hal inilah yang menyebabkan sampai saat ini varietas unggul nilam yang telah dilepas masih sangat terbatas. Salah satu upaya yang dapat dilakukan untuk meningkatkan mutu genetik tanaman adalah melalui pemuliaan tanaman yaitu dengan induksi mutasi.

Kolkisin dipercaya dapat digunakan untuk meningkatkan keragaman fenotipe maupun keragaman genotipe dari suatu tanaman. Hasil penelitian Anggraeni et al.,2017) menggunakan kolkisin pada tanaman jagung menunjukkan adanya keragaman pada genotipe jagung mutan generasi $\mathbf{M}_{2}$ hasil perlakuan kolkisin. Tanaman yang diberi perlakuan kolkisin sangat berbeda dengan tanaman kontrol untuk setiap karakter yang diamati diantaranya adalah warna biji, tinggi tanaman, jumlah daun, lebar daun, lebar stomata dan umur berbunga.

Konsentrasi kolkisin yang digunakan dan lama perendaman yang tepat akan menghasilkan keanekaragaman yang tinggi, akan tetapi jika konsentrasi kolkisin yang digunakan terlalu tinggi maka akan merusak sel tanaman bahkan dapat menyebabkan tanaman mati. Setiap tanaman akan memberikan respon yang berbeda sehingga dibutuhkan penelitianpenelitian untuk melihat konsentrasi dan lama perendaman yang sesuai untuk setiap tanaman. Induksi poliploidi dapat memperbaiki karakter dan ukuran dari tanaman. Salah satu fase pertumbuhan cepat pada tanaman dimana sel-sel sedang aktif membelah adalah fase juvenil (bibit). Jika aplikasi kolkisin dilakukan pada fase tersebut diduga dapat memperbesar peluang diperolehnya sel-sel diploid Rahayu et al., (2015).

Perubahan yang dihasilkan melalui induksi mutasi menggunakan kolkisin ini dapat menjadi upaya dalam menghasilkan varietas nilam baru yang lebih unggul. Salah satu varietas nilam Aceh yang memiliki kadar minyak yang tinggi adalah varietas Lhokseumawe yaitu sekitar 3,21\% sedangkan kadar Patchouli Alcohol (PA) nya masih rendah dibandingkan varietas Tapaktuan (Kementerian Pertanian, 2018). Nilam varietas Lhokseumawe memiliki sifat daya adaptasi tinggi dan batangnya 
berwarna ungu kehijauan. Hasil penelitian Endra (2018) menunjukkan adanya pengaruh terhadap tinggi tanaman, luas daun dan jumlah cabang akibat perlakuan konsentrasi kolkisin $(0.25 \%, 0.50 \%$ dan $0.75 \%)$ dan lama perendaman $(2,4,6,8$ jam) pada stek nilam varietas Lhokseumawe.

Penelitian kami ini bertujuan untuk mengetahui pengaruh konsentrasi kolkisin $(0 \%, 1 \%, 2 \%$ dan $3 \%)$ dan lama perendaman yang berbeda $(2,4,6$, dan 8 jam) terhadap pertumbuhan bibit nilam varietas Lhokseumawe.

\section{METODE}

Penelitian ini dilaksanakan di Kebun Percobaan Dua, Sektor Timur, Fakultas Pertanian, Universitas Syiah Kuala, Darussalam, Banda Aceh yang berlangsung dari bulan Juni 2020 sampai dengan September 2020.

Alat yang digunakan dalam penelitian ini antara lain kertas label, pengait label, polybag ukuran $17 \mathrm{~cm}$ x $40 \mathrm{~cm}$, cangkul, paranet, meteran, jangka sorong, ember, timbangan analitik, masker, sarung tangan, sprayer, gelas ukur, kamera dan peralatan tulis. Bahan yang digunakan dalam penelitian ini adalah bibit nilam varietas Lhokseumawe umur 2 bulan sebanyak 64 batang, bubuk kolkisin, aquades, tanah sebanyak $200 \mathrm{~kg}$, dan pupuk kandang sebanyak $100 \mathrm{~kg}$.

Penelitian ini menggunakan Rancangan Acak Kelompok (RAK) faktorial dengan dua faktor. Faktor pertama adalah konsentrasi (K) larutan kolkisin yang terdiri dari 4 taraf $(\mathrm{K} 0=0 \% ; \mathrm{K} 1=1 \%$; $\mathrm{K} 2=2 \%$; $33=3 \%$ ). Faktor kedua adalah lama perendaman (W) didalam larutan kolkisin yang terdiri dari 4 taraf $(\mathrm{W} 1=2$ jam; $\mathrm{W} 2=4 \mathrm{jam} ; \mathrm{W} 3=6 \mathrm{jam} ; \mathrm{W} 4=8 \mathrm{jam}$ ).

Berdasarkan faktor percobaan yang digunakan terdapat 16 kombinasi perlakuan dan masing-masing perlakuan diulang sebanyak 4 kali, sehingga secara keseluruhan terdapat 64 satuan unit percobaan.
Data hasil penelitian dianalisis menggunakan F (ANOVA), apabila menunjukkan pengaruh yang nyata $(\alpha=$ $5 \%$ ), maka dilakukan analisis lanjut menggunakan uji Duncan Multiple Range Test (DMRT) pada taraf 5\%.

Lahan yang digunakan sebagai tempat pelaksanaan penelitian dibersihkan dari sampah dan gulma lalu diberikan alas berupa terpal, kemudian di sekeliling tempat penelitian dilakukan pemasangan paranet. Setiap sisi paranet dikaitkan dengan sisi lainnya sehingga tidak mudah terlepas dan rusak.

Bahan tanam yang digunakan adalah bibit nilam varietas Lhokseumawe berumur sekitar 2 bulan yang diperoleh dari kebun pembibitan Atsiri Research Center (ARC). Bibit tanaman nilam yang digunakan sebanyak 64 batang, dengan ukuran tanaman yang seragam dalam hal tinggi tanaman, jumlah daun dan jumlah cabangnya. Setiap batang bibit nilam langsung diberikan label sesuai perlakuan untuk memudahkan saat proses perendaman dan penanaman.

Bahan media yang digunakan adalah media tanam yang terdiri dari komposisi campuran tanah dan pupuk kandang. Tanah yang digunakan adalah tanah lapisan atas (top soil), sedangkan pupuk kandang yang digunakan adalah pupuk kandang sapi yang telah mengalami dekomposisi, diperoleh dari kebun pembibitan tanaman rakyat. Tanah dan pupuk kandang diayak menggunakan ayakan 10 mesh lalu dicampur dengan perbandingan berdasarkan volume 2 tanah : 1 pupuk kandang. Media tanam yang telah dicampur dimasukkan ke dalam polybag berukuran $17 \mathrm{~cm} \mathrm{x} 40 \mathrm{~cm}$ dengan volume $3 \mathrm{~kg}$, selanjutnya dilakukan pelabelan pada polybag. Polybag disusun acak berdasarkan kelompok atau ulangannya dan media tanam didiamkan selama \pm 14 hari sebelum ditanam.

Larutan kolkisin dibuat dalam ember dengan melarutkan bubuk kolkisin dalam air sebanyak 2 liter. Pembuatan larutan 
kolkisin disesuaikan berdasarkan konsentrasi kolkisin yang digunakan. Larutan kolkisin dengan konsentrasi $1 \%$ digunakan bubuk kolkisin sebanyak $20 \mathrm{mg}$ yang dilarutkan dalam 2-liter air. Untuk konsentrasi 2\% dibutuhkan bubuk kolkisin sebanyak $40 \mathrm{mg}$ dan untuk konsentrasi 3\% dibutuhkan bubuk kolkisin sebanyak 60 mg. Proses pembuatan larutan kolkisin diawali dengan mengisi air sebanyak 1-liter kedalam gelas ukur, kemudian bubuk kolkisin dicampurkan kedalam air tersebut lalu dicukupkan hingga 2 liter. Masingmasing larutan kolkisin dibuat sesuai perlakuan dan diisi ke dalam ember, kemudian setiap ember diberikan label sesuai perlakuan.

Bibit nilam diambil satu-persatu dan dibongkar dengan hati-hati agar tidak merusak perakarannya, kemudian akarnya dicuci dan dibersihkan dari sisa tanah yang menempel. Bibit nilam yang telah bersih dimasukkan kedalam ember yang berisi larutan kolkisin sesuai dengan konsentrasi dan waktu perendaman yang telah dibuat. Tanaman nilam tersebut direndam secara bertahap setiap 2 jam sekali diawali dari perendaman untuk 8 jam, 6 jam, 4 jam dan 2 jam. Perendaman secara bertahap ini dilakukan agar proses penanaman dapat dilakukan serentak di waktu yang sama. Setelah proses perendaman siap dilakukan, akar tanaman kembali dicuci menggunakan aquades.

Penanaman bibit nilam diawali dengan membuat lubang tanam pada polybag dengan cara tugal disesuaikan dengan panjang akarnya agar perakaran bibit nilam tidak rusak. Kemudian bibit nilam diletakkan dalam lubang tanam dan tanah dipadatkan kembali sampai menutupi perakaran agar tanaman tidak mudah rebah.

Pemeliharaan yang dilakukan setelah perlakuan meliputi penyiraman, penyiangan gulma serta pengendalian hama dan penyakit. Penyiraman dilakukan cukup sekali dalam sehari yaitu pagi hari dan disesuaikan dengan tingkat kelembaban pada media tanam. Jika media tanam terlalu basah atau lembab, maka tidak perlu dilakukan penyiraman. Penyiangan gulma dilakukan secara fisik apabila diperlukan dengan cara mencabut gulma yang tumbuh di dalam polybag. Penyiangan gulma juga dilakukan pada sekitar tempat penelitian agar terhindar dari hama dan penyakit yang menjadikan gulma sebagai sarangnya. Pengendalian hama kutu putih dan semut masih menggunakan pestisida nabati (bawang putih, sereh dan sunlight) karena masih sedikit dan masih dalam skala yang kecil.

Semua parameter pengamatan dilakukan sebelum dan sesudah diberi perlakuan kolkisin. Pengamatan sebelum perlakuan dilakukan sehari sebelum perlakuan, sedangkan pengamatan setelah perlakuan dilakukan setiap 30 hari sekali selama 90 hari. Parameter pengamatan yang dilakukan diantaranya adalah: 1) Pertambahan tinggi tanaman diukur pada saat tanaman berumur 30, 60, 90 HSP (hari setelah perlakuan). Pengukuran dilakukan mulai dari pangkal batang yang telah diberi tanda sampai titik tumbuh cabang tertinggi pada setiap tanaman, untuk mendapatkan data pertambahan tinggi maka tinggi tanaman setelah perlakuan dikurangi tinggi pengamatan sebelum perlakuan; 2) Pertambahan diameter batang diukur pada saat tanaman berumur 30, 60, 90 HSP. Pengukuran dilakukan menggunakan jangka sorong dengan cara mengukur bagian pangkal batang dari setiap tanaman, untuk mendapatkan data pertambahan diameter maka diameter tanaman setelah perlakuan dikurangi diameter pada pengamatan sebelum perlakuan; 3) Jumlah cabang diamati pada saat tanaman berumur 30, 60, 90 HSP. Pengamatan jumlah cabang dilakukan dengan menghitung seluruh cabang yang tumbuh pada setiap tanaman; 4) Jumlah tunas diamati pada saat tanaman berumur 30, 60, 90 HSP. Pengamatan jumlah tunas dilakukan dengan menghitung seluruh tunas yang muncul pada setiap ruas batang utama juga pada setiap ruas daun dan cabang; 5) Jumlah helai daun diamati 
pada saat tanaman berumur 30, 60, 90 HSP. Daun yang dihitung adalah daun yang telah membuka sempurna, jika daun telah layu dan menguning tidak dihitung lagi; 6) Panjang cabang diamati pada saat tanaman berumur 30, 60, 90 HSP. Pengukuran panjang cabang dilakukan dengan menghitung panjang dari masing-masing cabang pada setiap tanaman lalu dirataratakan; 7) Luas permukaan daun hanya diamati dua kali yaitu sebelum dilakukan perlakuan dan sesudah dilakukan perlakuan. Pengukuran luas permukaan daun dilakukan menggunakan software imageJ. Setiap tanaman diambil tiga daun secara acak untuk mewakili setiap tanaman. Daun yang dipilih dalam keadaan baik dan diusahakan berada pada posisi yang sama. Ketiga daun tersebut difoto di atas kertas HVS putih dan diberi penggaris pada tepi kiri HVS. Daun yang telah diletakkan di atas HVS difoto beserta penggarisnya. Hasil foto dimasukkan ke software dan dihitung luas per helai daun tersebut lalu dirata-ratakan; 8) Nilai LD50 dibutuhkan untuk mengetahui konsentrasi optimal dalam menghasilkan keragaman genetik sehingga dapat menjadi acuan bagi penelitian selanjutnya. Keragaman genetik tertinggi didapatkan pada konsentrasi disekitar nilai $\mathrm{LD}_{50}$. Nilai $\mathrm{LD}_{50}$ menunjukkan besarnya konsentrasi dari induksi mutasi yang dapat mematikan $50 \%$ populasi tanaman. $\mathrm{LD}_{50}$ dihitung berdasarkan persentase daya tumbuh pada MV1 dari setiap konsentrasi yang digunakan $(1 \%, 2 \%, 3 \%)$. Nilai $\mathrm{LD}_{50}$ ini dihitung pada saat tanaman berumur 30 hari setelah perlakuan.

\section{HASIL DAN PEMBAHASAN}

Secara umum penelitian ini membahas tentang respon tanaman nilam terhadap faktor konsentrasi kolkisin dan lama perendaman terhadap beberapa peubah pertumbuhan. Berdasarkan penelitian yang telah dilakukan konsentrasi kolkisin $1 \%, 2 \%$ dan $3 \%$ tidak menyebabkan kematian populasi tanaman nilam MV1 ini dan semua tanaman nilam yang telah diberi perlakuan kolkisin dapat tumbuh hingga umur 90 HSP. Hasil penelitian menunjukkan bahwa perlakuan konsentrasi kolkisin dan lama perendaman yang digunakan tidak berpengaruh yang nyata terhadap sebagian besar peubah yang diamati, hal ini diduga karena setiap tanaman memiliki respon yang berbeda terhadap pemberian kolkisin. Perubahan yang terjadi pada tanaman akibat perlakuan kolkisin sangat bervariasi karena kolkisin mempengaruhi hanya sebagian sel tanaman dan hanya efektif pada sel yang sedang aktif membelah (Aili et al., 2016).

Rata-rata pertambahan tinggi tanaman nilam akibat perlakuan konsentrasi kolkisin dapat dilihat pada Tabel 1 . Pertambahan tinggi tanaman pada umur 60 HSP cenderung paling banyak dijumpai pada perlakuan konsentrasi kolkisin $2 \%$, tetapi pada umur 90 HSP pertambahan tinggi tanaman paling banyak dijumpai pada konsentrasi kolkisin 1\%. Perlakuan kolkisin menyebabkan aktivitas metabolisme tanaman menjadi terhambat. Maghfirah et al., (2018) menyatakan bahwa pemberian kolkisin dapat membuat ukuran sel menjadi lebih besar sehingga pembelahan sel berlangsung lebih lambat. Hal inilah yang menyebabkan pertumbuhan suatu tanaman yang telah diberi perlakuan kolkisin menjadi lambat. Perlakuan konsentrasi $3 \%$ juga menghasilkan rerata panjang cabang tertinggi. Hal ini sesuai dengan pernyataan Sartika dan Basuki (2017) yang menyatakan bahwa konsentrasi kolkisin yang tepat akan memberikan dampak positif pada jaringan tanaman dan tidak menyebabkan kemunduran pada pertumbuhannya karena pengaruh dari kolkisin masih dapat ditoleransi oleh jaringan tanaman.

Perlakuan kontrol menghasilkan diameter batang, jumlah daun, jumlah cabang dan jumlah tunas yang lebih banyak dibandingkan tanaman yang mendapat perlakuan kolkisin, akan tetapi perlakuan konsentrasi $2 \%$ juga memiliki potensi 
jumlah cabang, jumlah daun dan jumlah tunas yang tinggi, akan tetapi laju pertumbuhannya lebih lambat (Tabel 2). Hal ini sesuai dengan hasil penelitian Sutrisno dan Kuswantoro (2014) pada tanaman kedelai dimana rata-rata pertumbuhan jumlah cabang dan tunas dengan pemberian kolkisin lebih lambat dibandingkan dengan tanaman tanpa pemberian kolkisin (kontrol). Hal ini analog bahwa pemberian kolkisin dapat menghambat terjadinya pertunasan pada tanaman nilam yang disebabkan oleh gangguan fisiologis yang menyebabkan tingkat pembelahan sel menurun. Afifah (2015) berdasarkan hasil penelitiannya, menyatakan bahwa konsentrasi kolkisin yang terlalu tinggi dapat menghambat proses proliferasi tunas sehingga menyebabkan pertumbuhan tunas terhambat. Hal yang sama juga terjadi pada penelitian Nugroho (2015) yang menjelaskan bahwa pemberian kolkisin pada tanaman dapat mengakibatkan pertumbuhan tanaman tertunda akibat dari rusaknya jaringan tanaman sehingga membutuhkan waktu yang lama untuk tumbuh.

Tabel 1. Rata-rata pertambahan tinggi tanaman nilam pada umur 30, 60 dan 90 HSP akibat perlakuan konsentrasi kolkisin

\begin{tabular}{cccc}
\hline \multirow{2}{*}{$\begin{array}{c}\text { Konsentrasi } \\
\text { Kolkisin } \\
(\%)\end{array}$} & \multicolumn{3}{c}{$\begin{array}{c}\text { Pertambahan tinggi } \\
\text { tanaman }(\mathbf{c m})\end{array}$} \\
\cline { 2 - 4 } & 30 & 60 & 90 \\
$\mathrm{HSP}$ & HSP & HSP \\
\hline $\mathrm{K} 0(0 \%)$ & 7,69 & 20,13 & 29,00 \\
\hline $\mathrm{K} 1(1 \%)$ & 6,50 & 21,50 & 32,13 \\
\hline $\mathrm{K} 2(2 \%)$ & 7,19 & 22,19 & 31,50 \\
\hline $\mathrm{K} 3(3 \%)$ & 5,31 & 20,44 & 31,38 \\
\hline
\end{tabular}

Hasil analisis ragam menunjukkan perlakuan konsentrasi kolkisin berpengaruh nyata terhadap luas permukaan daun nilam (Tabel 3). Perlakuan konsentrasi 3\% memberikan pengaruh terbaik pada luas daun tanaman nilam setelah perlakuan, yang berbeda nyata dengan perlakuan konsentrasi $0 \%$ (kontrol).
Peningkatan konsentrasi kolkisin hingga $3 \%$ dapat membuat permukaan daun nilam lebih besar. Hal ini sejalan dengan penelitian Widoretno (2016) pada tanaman nilam yang menghasilkan perubahan morfologi tanaman tetraploid sangat signifikan dibandingkan dengan tanaman diploid dalam ukuran daun dan diameter batang. Pada konsentrasi kolkisin $60 \mathrm{mg} \mathrm{L}^{-1}$, tanaman tetraploid menunjukkan luas permukaan daun dan diameter batang lebih besar dibandingkan tanaman diploid, selain itu tanaman tetraploid yang dihasilkan memiliki warna hijau lebih gelap dan daun lebih tebal. Anne dan Wiendi (2011) menyatakan bahwa pemberian kolkisin pada tanaman dapat menyebabkan tingkat ploidi tanaman meningkat salah satunya dapat memperbesar bagian dari tanaman (akar, batang, daun, bunga dan buah).

Tabel 2. Rata-rata pertambahan diameter batang, jumlah daun jumlah cabang dan jumlah tunas pada umur 30, 60 dan 90 HSP akibat perlakuan konsentrasi kolkisin

\begin{tabular}{lccc}
\hline Konsentrasi & 30 & 60 & 90 \\
kolkisin (\%) & HSP & HSP & HSP \\
\hline \multicolumn{4}{l}{ Pertambahan diameter batang } \\
K0 (mm) \\
K0 $0 \%)$ & 1,65 & 3,35 & 4,5 \\
K1 (1\%) & 1,23 & 2,68 & 3.83 \\
K2 (2\%) & 1,16 & 2,68 & 3,89 \\
K3 (3\%) & 1,22 & 2,85 & 3,86 \\
Rata-rata jumlah daun \\
K0 (0\%) & 23,13 & 48.25 & 93,13 \\
K1 (1\%) & 19,19 & 43,13 & 83,75 \\
K2 (2\%) & 21,81 & 44,88 & 94,25 \\
K3 (3\%) & 21,25 & 42,19 & 86,06 \\
Rata-rata jumlah cabang & \\
K0 (0\%) & 2,19 & 4,81 & 9,88 \\
K1 (1\%) & 2,06 & 4,06 & 8,56 \\
K2 (2\%) & 2,25 & 4,69 & 9,50 \\
K3 (3\%) & 2,25 & 3,75 & 9,00 \\
Rata-rata jumlah Tunas & \\
K0 (0\%) & 11,0 & 15,63 & 13,50 \\
K1 (1\%) & 4,94 & 11,56 & 10,56 \\
K2 (2\%) & 8,81 & 15,44 & 13,38 \\
K3 (3\%) & 5,63 & 12,06 & 10,75 \\
\hline
\end{tabular}


Tabel 3. Rata-rata luas permukaan daun tanaman nilam pada umur 90 HSP akibat perlakuan konsentrasi kolkisin

\begin{tabular}{cc}
\hline $\begin{array}{c}\text { Konsentrasi } \\
\text { Kolkisin (\%) }\end{array}$ & $\begin{array}{c}\text { Rata-rata luas } \\
\text { permukaan } \\
\text { daun (cm2) }\end{array}$ \\
\hline K0 (0\%) & $48,59 \mathrm{a}$ \\
K1 (1\%) & $59,13 \mathrm{~b}$ \\
K2 (2\%) & $54,56 \mathrm{ab}$ \\
K3 (3\%) & $60,15 \mathrm{~b}$ \\
\hline
\end{tabular}

Keterangan: Angka yang diikuti oleh huruf yang sama pada kolom yang sama berbeda tidak nyata pada taraf 5\% (Uji DMRT 0,05 ).

Berdasarkan hasil penelitian tersebut dapat diduga bahwa kolkisin menyebabkan pertumbuhan tanaman melambat pada fase

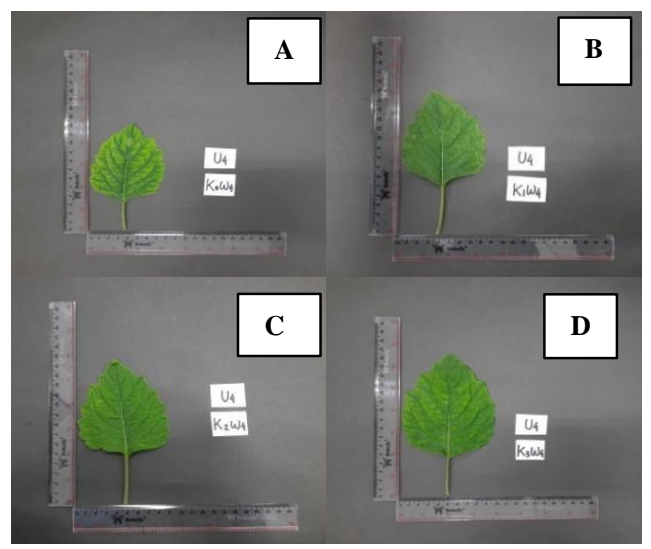

Gambar 1. Perbandingan luas permukaan daun nilam akibat perlakuan konsentrasi kolkisin: a) konsentrasi kolkisin 0\% (kontrol), b) konsentrasi kolkisin $1 \%$, c) konsentrasi kolkisin $2 \%$, dan d) konsentrasi kolkisin 3\%

Hal ini dapat terjadi karena banyak hal, diantaranya adalah tidak adanya kerusakan yang diakibatkan oleh mutagen kolkisin karena konsentrasi kolkisin yang kurang tepat sehingga pertumbuhan tanaman cenderung sama atau pengaruh kolkisin bekerja lambat sehingga belum terlihat dalam waktu pengamatan $90 \mathrm{HSP}$.

Hasil penelitian menunjukkan bahwa lama perendaman dengan kolkisin secara statistik berdasarkan uji $\mathrm{F}$, tidak berbeda nyata pada taraf 5\%. Perlakuan lama perendaman yang tepat untuk menghasilkan pertambahan tinggi dan diameter tanaman awal pertumbuhan sehingga pengaruh kolkisin baru akan terlihat pada umur 60 dan 90 HSP. Hal ini diduga terjadi karena pengaruh dari kolkisin yang diberikan dapat menurunkan laju pertumbuhan. Hal ini juga sejalan dengan hasil penelitian Sartika dan Basuki (2017) dimana pertumbuhan tanaman dengan perlakuan kolkisin tertinggi $(1 \%)$ menghasilkan pertumbuhan tanaman yang lebih lambat dibandingkan tanaman kontrol.

Secara umum hasil penelitian ini tidak memiliki perbedaan antara setiap perlakuan konsentrasi kolkisin karena tidak adanya pengaruh yang nyata pada setiap parameter kecuali luas permukaan daun (Gambar 1).

nilam yang paling efektif adalah perendaman selama 2 jam dan 8 jam, seperti disajikan pada tabel 4. Hasil penelitian ini sedikit berbeda dengan hasil penelitian Pharmawati dan Suada (2013) pada tanaman cabai rawit yang menunjukkan bahwa perlakuan perendaman terbaik untuk menghasilkan tanaman tertinggi adalah perendaman 6 jam dimana tinggi tanaman terendah terdapat pada perendaman $12 \mathrm{jam}$. Perlakuan lama perendaman 2 jam memperlihatkan pertumbuhan jumlah cabang dan daun tertinggi dibandingkan perlakuan lainnya. Hal ini sejalan dengan penelitian Nursalmin et al., (2019) pada tanaman krisan yang menunjukkan bahwa jumlah daun dan buku tertinggi dijumpai pada perendaman 1 jam dimana rerata jumlah daun dan buku akan menurun seiring dengan penambahan waktu perendaman.

Perlakuan perendaman selama 6 jam menghasilkan pertumbuhan jumlah tunas yang paling tinggi pada penelitian ini. Hasil penelitian Rahayu et al., (2013) yang menghasilkan jumlah anakan tertinggi pada perlakuan perendaman 9 jam dibandingkan dengan perendaman 3, 6 dan 12 jam. Lama perendaman 8 jam menghasilkan rerata panjang cabang dan luas permukaan daun yang paling tinggi. Anne (2012) menyatakan bahwa waktu perlakuan 
kolkisin yang semakin lama akan berdampak pada rendahnya massa sel yang dapat beregenerasi yang sesuai dengan hasil penelitiannya yaitu persentase regenerasi tertinggi terjadi pada perendaman kolkisin 1 hari sedangkan yang paling rendah adalah dengan perendaman 7 hari. Perlakuan lama perendaman tidak berpengaruh terhadap semua parameter yang diamati, hal ini sejalan dengan hasil penelitian Endra (2018) terhadap stek nilam yang menyatakan bahwa lama perendaman 2 jam, 4 jam, 6 jam dan 8 jam tidak memberi pengaruh terhadap tinggi tanaman, luas daun dan jumlah cabang. Lama perendaman tersebut belum sesuai untuk pertumbuhan tanaman nilam varietas Lhokseumawe sehingga diperlukan waktu perendaman lebih lama.

Kombinasi perlakuan konsentrasi kolkisin dengan lama perendaman pada umur 30 HSP menghasilkan jumlah cabang terbanyak pada konsentrasi kolkisin $2 \%$ dengan lama perendaman 6 jam, diikuti dengan konsentrasi kolkisin 3\% dengan perendaman 2 jam (Tabel 5). Peningkatan konsentrasi kolkisin hingga 3\% dan lama perendaman hingga 8 jam masih dapat menghasilkan jumlah cabang yang tinggi. Beberapa hasil penelitian penggunaan kolkisin terhadap tanaman lain juga dapat menghasilkan pertumbuhan yang tidak sejalan, seperti pada penelitian Ermayanti et al., (2018) pada tanaman talas yang menyatakan bahwa semakin tinggi konsentrasi dan lama perendaman dalam kolkisin akan menghasilkan jumlah tunas anakan yang semakin sedikit. Terhambatnya pertumbuhan tunas diduga karena perlakuan perendaman dan konsentrasi kolkisin mengakibatkan proses pembelahan sel menjadi abnormal.

Setiap spesies bahkan setiap bagian tanaman memiliki kepekaan dan respon yang sangat berbeda terhadap konsentrasi kolkisin dan waktu perlakuan tergantung jenis dan organ tanaman yang diberi perlakuan. Oleh karena itu terdapat beragam hasil dari konsentrasi kolkisin dan lama perendaman yang digunakan untuk menginduksi poliploidi secara optimal.

Tabel 4. Rata-rata pertambahan tinggi tanaman, diameter batang, jumlah daun, jumlah cabang dan jumlah tunas pada umur 30, 60 dan 90 HSP akibat perlakuan lama perendaman

\begin{tabular}{lccc} 
Lama & $\mathbf{3 0}$ & $\mathbf{6 0}$ & $\mathbf{9 0}$ \\
perendaman & HSP & \multicolumn{3}{c}{ HSP } & HSP \\
\hline Pertambahan tinggi tanaman $(\mathrm{cm})$ \\
\hline W1 (2 jam) & 7,13 & 22,31 & 31,94 \\
\hline W2 (4 jam) & 5,44 & 19,44 & 30,13 \\
\hline W3 (6 jam) & 7,38 & 21,25 & 30,69 \\
\hline W4 (8 jam) & 6,75 & 21,25 & 31,25 \\
\hline Pertambahan diameter batang (mm) \\
W1 (2 jam) & 1,34 & 3,10 & 4,34 \\
W2 (4 jam) & 1.43 & 3,12 & 4.24 \\
W3 (6 jam) & 1,35 & 2,73 & 3,82 \\
W4 (8 jam) & 1.13 & 2,62 & 3,71 \\
Rata-rata jumlah daun & \\
W1 (2 jam) & 23,06 & 52,81 & 102,44 \\
W2 (4 jam) & 18,69 & 45,06 & 85,56 \\
W3 (6 jam) & 21,13 & 40,13 & 88,69 \\
W4 (8 jam) & 22,50 & 40,44 & 80,50 \\
Rata-rata jumlah cabang & \\
W1 (2 jam) & 2,69 & 5,25 & 10,56 \\
W2 (4 jam) & 1,94 & 4,19 & 8,81 \\
W3 (6 jam) & 2,38 & 3,25 & 9,13 \\
W4 (8 jam) & 2,63 & 4,63 & 8,44 \\
Rata-rata jumlah tunas & \\
W1 (2 jam) & 8,13 & 14,13 & 19,88 \\
W2 (4 jam) & 6,50 & 13,00 & 18,88 \\
W3 (6 jam) & 8,25 & 16,69 & 21,44 \\
W4 (8 jam) & 7,50 & 10,88 & 15,00 \\
\hline \multicolumn{5}{c}{}
\end{tabular}

Kolkisin diketahui bersifat toksik bagi tanaman sehingga penggunaan kolkisin dapat menurunkan pertumbuhan vegetatif tanaman pasca induksi poliploid. Wolfe (1983) dalam Ermayanti et al., (2018) menyatakan bahwa kolkisin dapat menghambat pembentukan mikrotubula penyusun rangka sel dan merusak tata letak protein pada membran sel yang dikendalikan oleh mikrotubula dan mikrofilamen. Hal ini menyebabkan molekul-molekul dalam sitoplasma tidak terdistribusi dengan baik dan 
mengakibatkan pertumbuhan tanaman menjadi lambat.

Tabel 5. Rata-rata jumlah cabang tanaman nilam pada umur 30 HSP akibat interaksi konsentrasi kolkisin dengan lama perendaman.

\begin{tabular}{ccccc}
\hline \multirow{2}{*}{$\begin{array}{c}\text { Konsentrasi } \\
(\%)\end{array}$} & W1 $(2 \mathrm{jam})$ & $\mathrm{W} 2(4 \mathrm{jam})$ & $\mathrm{W} 3(6 \mathrm{jam})$ & $\mathrm{W} 4(8 \mathrm{jam})$ \\
\cline { 2 - 5 } $\mathrm{K} 0(0 \%)$ & $2,00 \mathrm{Aab}$ & $3,00 \mathrm{Dd}$ & $1,75 \mathrm{Aa}$ & $2,25 \mathrm{Abc}$ \\
$\mathrm{K} 1(1 \%)$ & $3,00 \mathrm{Cc}$ & $0,75 \mathrm{Aa}$ & $2,25 \mathrm{BCb}$ & $2,75 \mathrm{BCc}$ \\
$\mathrm{K} 2(2 \%)$ & $2,50 \mathrm{Bb}$ & $1,75 \mathrm{Ba}$ & $3,50 \mathrm{Dc}$ & $2,50 \mathrm{ABb}$ \\
$\mathrm{K} 3(3 \%)$ & $3,25 \mathrm{Cc}$ & $2,25 \mathrm{Cab}$ & $2,00 \mathrm{Ba}$ & $3,00 \mathrm{Cc}$ \\
\hline
\end{tabular}

Keterangan: Angka yang Diikuti oleh Huruf yang Sama (Huruf Kapital dilihat secara vertikal dan Huruf Kecil dilihat secara Horizontal) Berbeda Tidak Nyata pada Taraf 5\% (Uji DMRT 0,05 ).

Pendugaan awal dari penggunaan kolkisin yang tidak berpengaruh adalah karakter fisik akibat mutasi belum terlihat pada populasi MV1 dan diduga baru muncul saat generasi selanjutnya yaitu MV2 dan kelanjutannya. Pernyataan tersebut juga diungkapkan oleh Aili et al., (2016) pada penelitiannya terhadap tanaman jagung. Hal ini juga didukung oleh pernyataan Kristina dan Syahid (2015) yang menyatakan bahwa kerusakan fisiologis akibat perlakuan kolkisin hanya terjadi pada generasi pertama, sedangkan mutasi kromosom dan mutasi sitoplasma akan diturunkan pada generasi selanjutnya. Oleh karena itu, pengamatan karakter morfologi lanjutan hingga beberapa generasi terhadap tanaman nilam ini perlu dilakukan untuk mengetahui pertumbuhan fenotip dari tanaman nilam pasca diinduksi menggunakan kolkisin.

\section{SIMPULAN}

Konsentrasi kolkisin 3\% pada 90 HSP menghasilkan luas permukaan daun terbesar. Perlakuan lama perendaman tidak berpengaruh nyata terhadap semua peubah yang diamati. Konsentrasi kolkisin 2\% dengan lama perendaman 6 jam menghasilkan jumlah cabang tertinggi pada tanaman nilam umur 30 HSP.

Saran untuk penelitian selanjutnya melakukan pengamatan lebih dari 90 HSP, karena efek dari kolkisin memiliki laju yang lambat. Perlu juga dilakukan penelitian lebih lanjut pada generasi MV2 agar efek dari mutasi lebih terlihat serta melakukan analisis kromosom untuk generasi MV2.

\section{ACKNOWLEDGEMENT}

Kami mengucapkan terima kasih banyak kepada Universitas Syiah Kuala, Kementerian Pendidikan dan Kebudayaan yang telah mendanai penelitian ini sesuai dengan surat perjanjian penugasan pelaksanaan penelitian lektor kepala Tahun Anggaran 2020 Nomor: 266/UN11/SPK/PNBP/2020 tanggal 17 Maret 2020.

\section{DAFTAR PUSTAKA}

Afifah, U. A. N. 2015. Evaluasi keragaan fenotipe nilam (Pogostemon cablin Benth.) hasil mutasi kromosom dengan kolkisin. Skripsi. Departemen Agronomi dan Hortikultura. Fakultas Pertanian Institut Pertanian Bogor. Bogor.

Aili, E. N., Respatijarti dan Sugiharto, A. N. 2016. Pengaruh pemberian kolkisin terhadap penampilan fenotipe galur inbrida jagung pakan (Zea mays L.) pada fase pertumbuhan vegetatif. Jurnal Produksi Tanaman. 4(5): 370377.

Anggraeni, M., Damanhuri dan Sugiharto, A. N. 2017. Keragaan beberapa genotipe jagung pakan/yellow corn (Zea mays L.) mutan kolkisin generasi M2. Jurnal Produksi Tanaman. 5(3): 500-505.

Anne, Y. P. 2012. Induksi mutasi melalui 
penggandaan kromosom nilam Varietas Sidikalang (Pogostemon cablin Benth.) dengan kolkisin secara in vitro. Skripsi. Departemen Agronomi dan Hortikultura. Fakultas Pertanian Institut Pertanian Bogor. Bogor.

Anne, Y. P. dan Wiendi, N. M. A. 2011. Induksi mutasi melalui penggandaan kromosom nilam Varietas Sidikalang (Pogostemon cablin Benth.) dengan kolkisin. Prosiding Simposium dan Seminar Bersama PERAGIPERHORTI-PERIPI-HIGI. Bogor.

Direktorat Jenderal Perkebunan. 2020. Statistik Perkebunan Indonesia Komoditas Nilam Tahun 2018-2020. Jakarta.

Endra. 2018. Upaya peningkatan keragaman genetik tanaman nilam (Pogostemon cablin Benth.) melalui mutasi kromosom dengan induksi kolkisin. Tesis. Pascasarjana Fakultas Pertanian. Universitas Syiah Kuala. Banda Aceh.

Ermayanti, T. M., Wijayanta, A. N. dan Ratnadewi, D. 2018. Induksi Poliploidi pada Tanaman Talas (Colocasia esculenta (L.) Schott) Kultivar Kaliurang dengan Perlakuan Kolkisin secara In Vitro.Jurnal Biologi Indonesia. 14(1): 91-102.

Hariyani, Widaryanto, E. dan Herlina, N. 2015. Pengaruh umur panen terhadap rendemen dan kualitas minyak atsiri tanaman nilam (Pogostemon cablin Benth.).Jurnal Produksi Tanaman. 3(3):205-211. https://media.neliti.com

Kristina, N. N., \& Syahid, S. F. (2015). Pengaruh kolkhisin terhadap penampilan lada (Piper nigrum L.) mutan dan analisis ploidi. Jurnal Penelitian Tanaman Rempah dan Obat. 21(3): 125-130.

Kurniasari, A. M., Adisyahputra dan Rosman, R. 2010. Pengaruh kekeringan pada tanah bergaram $\mathrm{NaCl}$ terhadap pertumbuhan tanaman nilam. Buletin Penelitian Tanaman Rempah dan Obat. 21(1): 18-27.

Maghfirah, Roviq, M. dan Nihayati, E. 2018. Pengaruh pemberian kolkisin terhadap keragaman pertumbuhan dua klon Temulawak (Curcuma xanthorrhiza Roxb.) secara in vitro. Jurnal Produksi Tanaman. 6(6): 10001004.

Nugroho, Y. A. 2015. Induksi poliploid dengan kolkisin pada tanaman anggrek Dendrobium lasianthera (J.J Smith) secara in vitro. Skripsi. Departemen Agronomi dan Hortikultura. Fakultas Pertanian Institut Pertanian Bogor. Bogor.

Nursalmin, A., Komariah, A. dan Hidayat, O. 2019. Pengaruh lama perendaman kolkisin terhadap pertumbuhan planlet (Chrysanthemum morifolium R.) krisan Varietas Pasopati cara in vitro. Jurnal Ilmiah Pertanian. 6(2): 124-133.

Pharmawati, M. dan Suada, I. K. 2013. Peningkatan kualitas genetik cabai rawit (Capsicum frutescens L.) melalui teknologi mutasi untuk ketahanan terhadap Layu Fusarium. Universitas Udayana. Denpasar.

Rahayu, E. M. D., Sukma, D., Syukur, M., Aziz, S. A. dan Irawati. 2015. Induksi poliploidi menggunakan kolkisin secara in vivo pada bibit anggrek bulan (Phalaenopsis amabilis (L.) Blume). Buletin Kebun Raya LIPI. 18(1): 4148.

Rahayu, Y. S., Prasetyo, I. K. dan Riada, A. U. 2013. Pengaruh penggunaan kolkisin terhadap pertumbuhan vegetatif tanaman sedap malam (Polianthes tuberosa L.) di dataran medium. Fakultas pertanian Universitas Wisnuwardhana. Malang.

Sartika, T. V. dan Basuki, N. 2017. Pengaruh konsentrasi kolkisin terhadap perakitan putative mutan semangka (Citrullus lanatus). Jurnal Produksi Tanaman. 5(10):1669-1677.

Sutrisno dan Kuswantoro, H. 2014. Keragaan dua varietas kedelai pada enam konsentrasi kolkisin. Balai 
Penelitian Tanaman Aneka Kacang dan Umbi. 128-134. http://balitkabi.litbang.pertanian.go.id /wp-content/uploads/2015/05/128134_Sutrisno-1.pdf

Widoretno, W. 2016. In vitro induction and characterization of tetraploid Patchouli (Pogostemon cablin Benth.) plant. Plant Cell, Tissue and Organ Culture.125(2):261-267. https://doi.org/10.1007/s11240-0160946-0 